\title{
A figuração pós-moderna: Marta Brum, de Anjos da Noite
}

Renato PuCCi JR. 


\section{Resumo}

Através da análise da personagem Marta Brum, de Anjos da Noite (Wilson Barros, 1987), expõem-se características do que pode ser denominado "cinema pós-moderno". Conceitos de Baudrillard e Lyotard são examinados a fim de esclarecer o que seria o pós-modernismo cinematográfico: uma estética que problematiza a referencialidade e que se pauta pela idéias de performance e jogo. $\mathrm{O}$ filme analisado seria um exemplar dentre vários que, desde meados dos anos oitenta, seguiram a mesma estética no cinema nacional.

\section{Palavras-chave}

cinema brasileiro, pós-modernismo, camp, esteticismo, fake, jogo

\section{Abstract}

Through the analysis of Marta Brum, character of Anjos da Noite (Wilson Barros, 1987), traits of the so called "postmodern cinema" are exposed. Concepts of Baudrillard and Lyotard are examined in order to clarify what cinematographic postmodernism is: an aesthetic which questions the reference to the real world and which is driven by the ideas of performance and game. The analyzed movie is one of a number which have followed the same aesthetic in Brazilian cinema since the mid-eighties.

\section{Key words}

brazilian cinema, postmodernism, camp, aestheticism, fake, game 
câmera está à frente do veículo e, através do pára-brisa, enquadra três pessoas que conversam: Guto (interpretado por Marco Nanini) à direita, dirigindo; Marta Brum (Marília Pêra) à esquerda;Teddy no banco traseiro. É a mulher que fala, aludindo a Nova York, cidade onde mora Guto. A voz dela não poderia ser mais afetada, com entonações que buscam elegância e sofisticação, mas que, de tão exageradas, deixam claro que fala como se estivesse encenando um papel. Aliás, Marta confirma que é atriz ao dizer que saiu do Brasil somente uma vez, indo à Europa por haver ganho um prêmio de interpretação. Seu visual é o de uma estrela: vestido de noite, casaco de pele, colar de pérolas dando voltas no pescoço, brincos enormes e cravejados de pedras, longa piteira, luvas acima do cotovelo, anéis faiscantes. Quem observar melhor verá que o rosto dessa personagem brilha no escuro da noite: há glitter em sua face, fazendo-a cintilar.

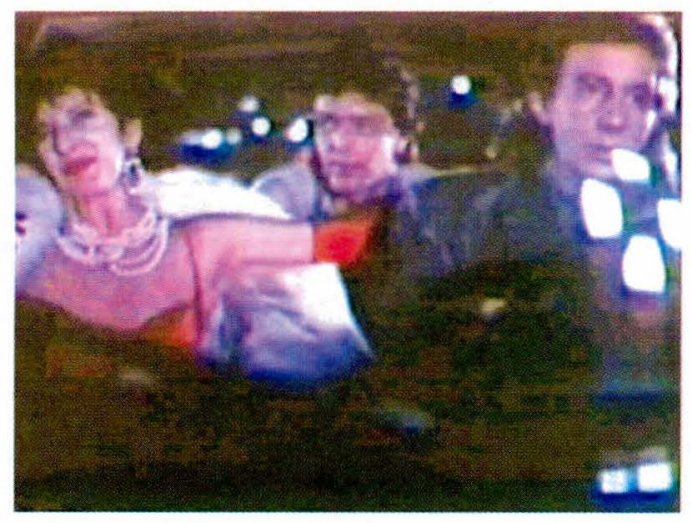

Fig. 1 
Conforme avança o diálogo, reflexos no pára-brisa deslizam à direita, sobre o tronco e o rosto de Guto: são as luminárias da avenida por onde passam, cuja imagem se reflete no vidro do carro (Fig. 1). Três vezes, em intervalos regulares, esses reflexos saem da base do vidro e atravessam toda a porção direita da tela até sumir na parte de cima. São luzes brancas e frias, como que a combinar com o estado de espírito de Guto, que está mudo, com evidente desprazer em relação ao que ouve.

A mulher conta, em seu estilo amaneirado, que durante toda a vida excursionou apenas pela "terrinha Brasilis", em tournées. Vem ao diálogo o tema que constituirá o eixo da cena: a passagem do tempo. Já faz seis anos que Teddy (Guilherme Leme) a viu pela primeira vez em Governador Valadares, cidade natal dele. A mulher solta um gritinho e exclama: "Meu Deeus! Quanto mais velho a gente fica, mais rápido o tempo passa!". Enquanto ela enuncia o batido lugar-comum, sobe na parte direita da tela o quarto reflexo de luminária da avenida; ao mesmo tempo, ergue-se à esquerda, ou seja, sobre o corpo da mulher, o reflexo dourado de uma torre. Já é possível saber por onde o automóvel está passando: aquela é uma das torres da Avenida Paulista, em São Paulo. Na época da realização do filme, meados dos anos oitenta, era a mais fascinante construção do tipo na cidade, uma estrutura esplendorosa, que depois viria a ser emulada por outras torres de transmissão.

Deve-se assistir ao filme no cinema para realmente experi-

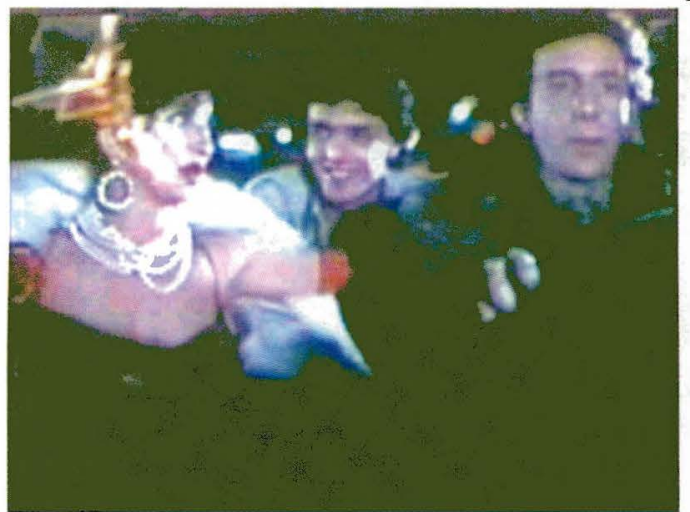

Fig. 2 mentar o impacto da cena. Marta Brum fala em como o tempo corre, e a imagem invertida da torre desliza sobre seu rosto, lentamente, numa composição visual fantástica, que multiplica o brilho que já existia no rosto dela (Fig. 2). É um dos momentos de magia 
do então jovem cinema paulista dos anos oitenta. O filme é Anjos da Noite, de Wilson Barros, lançado em 1987.

Neste trabalho pretendo examinar essa personagem que mereceu o coroa-mento visual acima descrito. Procurarei possíveis sentidos do virtuosismo cinematográfico que a acompanha e a consistência entre o ar fake de Marta Brum e o espírito que animou a estética do filme. Virtuosismo porque a suntuosidade da cena é alcançada por imaginativos recursos de estúdio que não mantêm ligação direta com a história. Ar fake porque tudo na personagem concorre para o artificialismo explícito e irônico. Qual é o jogo proposto ao espectador? Seriam gratuitos esses elementos? Ou será que responderam a precisas demandas espirituais que, deixando para trás o realismo, enveredaram por um fervor esteticista que talvez ainda não tenha arrefecido por completo?

\section{Uma estrela decadente}

O filme de Wilson Barros tem como característica mais evidente o fato de não possuir protagonista: inúmeros personagens são acompanhados alternadamente, em eixos narrativos que se entrecruzam, forma de narração que existe pelo menos desde os folhetins do século XIX e que foi apropriada pela literatura moderna, por exemplo no romance 1919, de John dos Passos. Esse formato tem rendido muitos filmes nas últimas décadas, com o cineasta norte-americano Robert Altman tornando-se seu especialista.

Aqui será seguido tão somente um dos fios narrativos de Anjos da Noite, isto é, aquele em que aparece Marta Brum. Sua primeira aparição ocorre bem antes da cena acima descrita: ela sai de um edifício e faz sinal para uma limusine, que pára (Fig. 3); um close mostra-a com ar blasé dar uma tragada no cigarro. A textura da imagem não é a de cinema, mas de TV, granulada e oscilante. De fato, o plano seguinte revela que se trata de um comercial de televisão assistido num bar por Guto e Teddy. Marta Brum está na propaganda com o mesmo figurino que usará na cena posterior. Até seus gestos, sempre estilizados e cheios de exagerado charme, são parecidos com os que apresentará ao se encontrar com os dois amigos. 


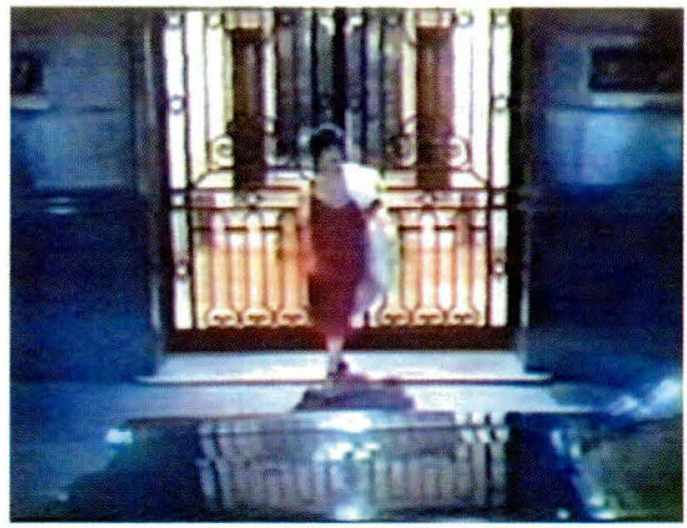

Fig. 3

Acabado o comercial, Guto e Teddy comentam a atriz, este falando que se "amarra" nela, o outro dizendo que a conheceu quando ela "ainda era estrela". A cena acaba logo em seguida. Só muito à frente o fio narrativo será retomado, ou seja, após o desenrolar das tramas paralelas de Anjos da Noite: as consequiências do assassinato de um inocente, a performance fracassada do artista de vanguar$\mathrm{da}$, o ménage à trois entre o casal de negros e a estudante de sociologia, o travesti que espera a chegada do amante etc. Enfim Guto e Teddy conhecem a moça do interior, vão com ela à boate gay e se divertem às custas da inocente; em seguida os dois saem pela noite, abraçados, pois foram amantes e há muito não se viam.

Numa rua escura, a câmera faz uma trajetória com a grua, descendo de uma placa de propaganda até o nível do chão; ao fundo surgem Guto e Teddy.' A câmera encontra uma mulher no primeiro plano. Ela estende o braço apontando para os dois e diz em tom faceiro: "Guto!". Este responde: "Marta Brum!" O rosto de Guto denota espanto pelo reencontro de uma amiga, reação ínfima diante do que a situação deveria suscitar: Marta está sentada como uma gata sobre o capô de uma limusine idêntica à que fora vista na TV; ela própria veste-se exatamente como sua personagem no comerci-

1. Construção tão estereotipada que serve para David Bordwell (1985, p. 66) exemplificar narraçōes autoconscientes, através de uma cena semelhante de Até a Vista, Querida (Edward Dmytryk, 1944). 
al: vestido vermelho e luvas da mesma cor, casaco branco de pele, piteira e tudo o mais; o prédio em frente ao qual está a limusine (Fig. 4) é o mesmo de que saíra Marta Brum na propaganda.

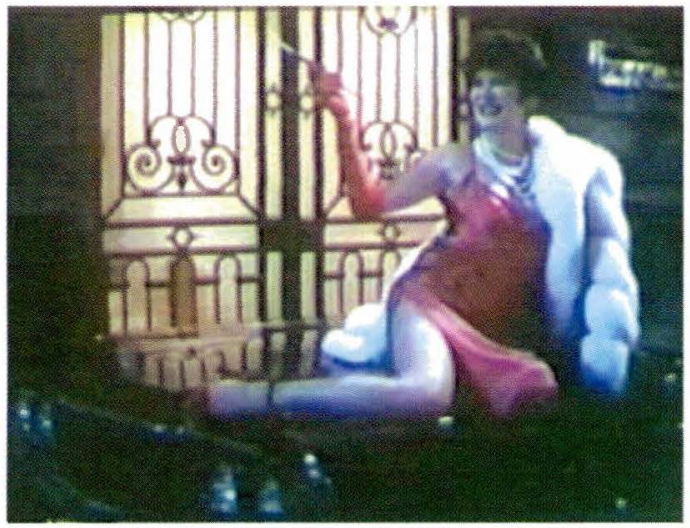

Fig. 4

O bom senso diria que a reação de Guto e Teddy deveria ser a perplexidade indagadora de Cecília, em A Rosa Púrpura do Cairo (Woody Allen, 1984), ao ver o personagem de um filme sair da tela, atravessar a platéia e caminhar em sua direção. No entanto, os dois nem sequer perguntam o que Marta estaria fazendo ali com todos os elementos do comercial visto na TV. Para eles, tudo aquilo é normal, ao contrário do que deve parecer para a maioria dos espectadores de Anjos da Noite. A reação destes pode ser a de procurar leituras consistentes a fim de normalizar o que assistiu (Iser, 1980, pp. 119-120); mas essa operação é altamente problemática quanto à cena em questão, pois o que estaria fazendo Marta Brum naquela rua deserta, à noite, como se tivesse acabado de gravar a peça publicitária que há pouco passou na TV? Fica-se perto do estranho freudiano, ou seja, aquela categoria do assustador que é, ao mesmo tempo, inquietantemente familiar. A conclusão se impõe: aquela que agora se vê em Anjos da Noite não é apenas Marta Brum, velha conhecida de Guto e ídolo de Teddy $3 / 4$ ela é também a personagem da propaganda. ${ }^{2}$

2. Note-se o entrelaçamento entre publicidade e cinema, traço típico de parte dos filmes contemporâneos e motivo para queixas de críticos para quem o cinema deve, a todo custo, evitar relações impuras como essa. A ligação, contudo, está imbricada na própria fatura de Anjos da Noite, com traços da personagem do comercial de TV reaparecendo em sua figura no mundo real. 
A continuação da cena irá mostrar que tudo o que compõe e faz Marta Brum nada mais é do que paródia: a natureza da personagem é a "diferença irônica no âmago da semelhança" (Hutcheon, 1991 , p. 12). Cada gesto e cada frase remetem ao universo do imaginário, seja o da publicidade ou o do cinema:

1) o jeito sofisticado de segurar a piteira;

2) a maneira como estende o braço na direção de Teddy, já esperando que ele beije sua mão;

3) a forma glamourosa com que cruza as pernas e se volta ora para um, ora para o outro de seus interlocutores;

4) o vestido vermelho talvez seja reminiscência de Torrentes de Paixão (Henry Hathaway, 1953), em que Marilyn Monroe usava um modelo da mesma cor e tão colado ao corpo como o de Marta; ${ }^{3}$

5) quando quer descer do capô da limusine, estende os braços na direção de Guto e Teddy, que a apóiam para que dê um pulinho até o chão;

6) enquanto espera que lhe ponham o casaco de pele, balança os quadris acintosamente.

Estes são apenas alguns elementos de Marta Brum que vêm carregados com o inconfundível ar de déjà vu. A crítica já apontou que personagens e ambientes em Anjos da Noite sempre são intertextuais:

a grade dos meios de comunicação [...] se abate sobre aquelas histórias, remetendo-as sistematicamente ao mundo da representação, apontando o oco que habita cada uma delas, insistindo no fato de que tudo, e todos, são texto, ficção (Ab'Saber, 1995, p. 144).

Marta Brum é a quintessência dessa caracterização, pois enquanto as demais personagens flutuam entre o naturalismo e esse pólo intertextual, Marta alude de maneira incessante ao imaginário, em especial à imagem de uma estrela de cinema (com um único momento de exceção, que será mencionado adiante). À maneira da dançarina de $O$ Fundo do Coração (Francis F. Coppola, 1982), interpretada por Nastassja Kinski, Marta Brum não tem substância

3. Figurino retomado na mulher virtual de Matrix (Andy e Larry Wachowski, 1999), filme que será comentado à frente. 
alguma, quase nada mais sendo além do que uma hiperconcentração de referências intertextuais. Ela é plana como um Roger Rabbit que se imiscuísse no universo diegético de Guto e Teddy. Como a confirmar sua natureza intertextual, ao término da sequiência em que encontra Guto e Teddy os três saem de braços dados ao som de "As Time Goes By", tema de Casablanca e canção cult da história do cinema. É o som do piano que aparecerá na sequiência posterior, sem a presença de Marta Brum e seus amigos, mas que invade o trecho descrito como se fosse música extradiegética, fazendo as vezes de comentário da narração ao caráter da personagem e, talvez, ao triângulo amoroso que se esboça.

É preciso ressaltar que Marta Brum não possui traços psicológicos: todas as suas reações se pautam pelo ar fingido e excessivo, numa exorbitância de superficialidade que a difere de quaisquer personagens fúteis e esnobes de filmes convencionais. A exceção que confirma a regra, isto é, o único momento em que ela parece derivar para a revelação de interioridade, ocorre durante a seqüência comentada no início deste artigo. Marta recorda-se de sua atuação em Governador Valadares, ocasião em que foi vista por Teddy. Ela diz que interpretou aquele papel durante quatro anos seguidos e que, com o tempo, começou a perceber que sua personagem não envelhecia nunca: o tempo não passava para ela, que morava no mesmo quartinho de papelão, vestia a mesma roupinha e repetia todas as noites as mesmas duas horas de sua vida. Marta conclui: "Minha personagem era eterna. E eu morri de inveja dela, eu morro de inveja dela, sempre jovem, jovem..." Ela, que hoje é uma estrela em fim de carreira, limitada a comerciais de televisão, demonstra uma ponta de aflição pelo correr do tempo. Ainda assim, enuncia a fala com a mão dobrada sob o queixo de Teddy, numa postura semelhante à de pinturas maneiristas do século XVI. É impossível dizer se ela é sincera ou se apenas continua a representar seu papel de diva em decadência.

Com essa pitada de suspeito naturalismo, a apologia à juventude e as carícias de Marta em Teddy terminam por enfurecer Guto, que se vê em dupla desvantagem: já não é tão jovem assim e, principalmente, está sendo trocado por uma mulher, pois Teddy se mostra 
fascinado por Marta. Guto pára o carro e, aos gritos, expulsa os dois. O fio narrativo prosseguirá apenas com Marta e Teddy.

\section{A apoteose fake}

Após uma série de flashs em que se mostram as situações de impasse nas histórias de Anjos da Noite, retorna-se a Marta e Teddy. Para quem conhece São Paulo não é difícil reconhecer o local: eles estão sob o MASP, o Museu de Arte de São Paulo. Teddy caminha acabrunhado enquanto Marta vai atrás fazendo firulas coreográficas, com voltas de $360^{\circ}$ sobre si mesma e poses de estupefata a cada revelação acerca do passado amoroso entre Teddy e Guto. As falas de Marta permanecem repletas de clichês, por exemplo:

O rapaz pergunta como ela adivinhou que Guto havia ido para Nova York, deixando Teddy sozinho nesta "cidade louca" e fazendo-o pirar. Marta diz em falsete: "Eu li nas cartas do Tarô, estava escrito nas estrelas", cantarolando versos da famosa canção da época.

Teddy conta que, já trabalhando como garoto de programa, uma noite foi chamado a um quarto de hotel e lá encontrou Guto, sem que ambos soubessem de nada a respeito um do outro. Comentário de Marta, balançando a cabeça com ar maternal: "Nada é nunca por acaso, meu anjo".

Teddy conta sua vingança contra Guto: este só pode encontrá-lo através da agência de "acompanhantes" e ainda tem que pagar para ficar com Teddy. Reação de Marta: põe as mãos na própria face, faz expressão de surpresa e diz: "Meu Deus, como você é cruel!".

Escuta-se música ao longe; o rapaz se ergue, olha pelo parapeito e vê lá embaixo duas pessoas em plena relação sexual num automóvel com o rádio ligado. Teddy levanta-se e anda com as mãos às costas. $\mathrm{O}$ corte introduz um plano escurecido que, de súbito, é iluminado por refletores; surge um palco sobre o qual caminha Teddy; a música ouvida do carro agora ocupa toda a trilha sonora, como se uma orquestra estivesse ali, ao lado de Teddy, completo absurdo em se tratando da diegese que se vinha desenvolvendo. É a famosa cena da dança no vão livre do MASP, escancarada paródia de um trecho 
Fig. 5 - A Roda da Fortuna
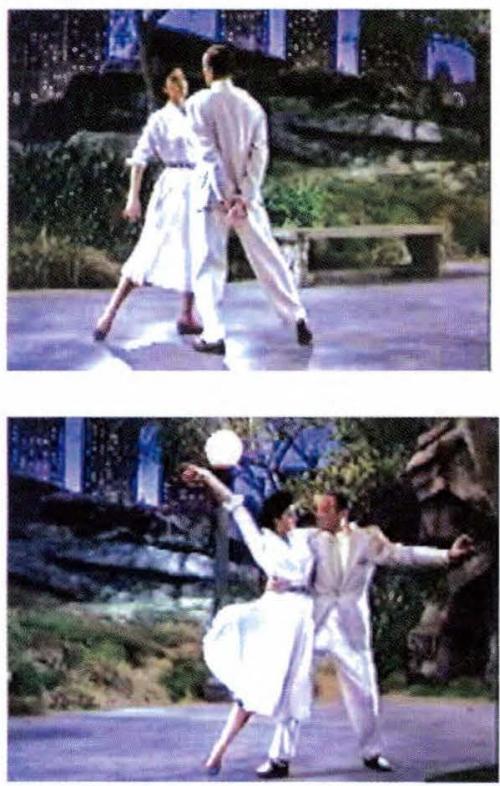

Fig. 6 - Anjos da Noite

Fig. 7 - A Roda da Fortuna
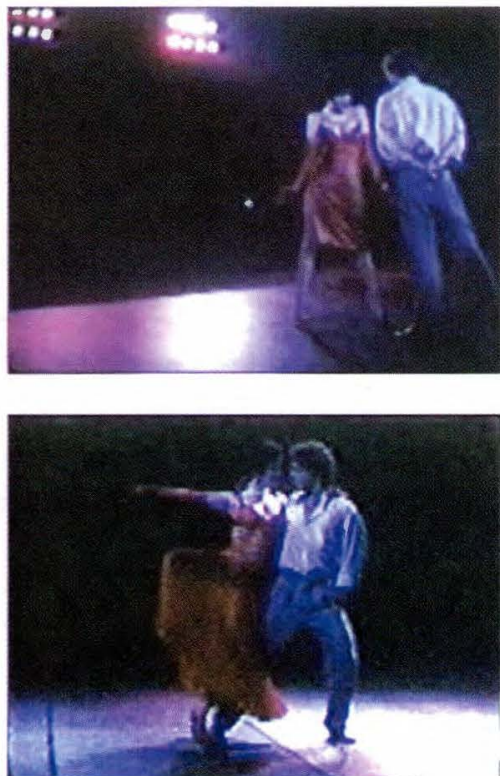

Fig. 8 - Anjos da Noite

de A Roda da Fortuna (The Band Wagon, de Vincente Minelli, 1953). Por mais que contextos e estilos cinematográficos sejam diferentes, percebe-se que é a mesma música ("Dancing in the Dark") e a mesma coreografia (Figs. 5 a 8 ).

Aqui devem ser observados dois pontos sem os quais Anjos da Noite não pode ser entendido. Em primeiro lugar, o filme não é só uma coleção de clichês da história do cinema. A cena da dança, por exemplo, não é simples repetição do musical hollywoodiano - de fato, ela é paródica: a diferença está no coração da semelhança. Afinal, nem de longe se espera que a performance dos atores de Wilson Barros se equiparem às de Fred Astaire e Cyd Charisse. A discrepância instala a distância entre o original e aquilo que nem sequer chega a ser uma cópia. Em suma, não se trata de repetição 
acadêmica, mas de uma paródia consciente e irônica que não existe para celebrar a imutabilidade dos valores. ${ }^{4}$ Em segundo lugar, ao se falar em paródia deve-se deixar de lado a idéia de que ela deva necessariamente envolver escárnio. Adoto aqui a acepção dada à palavra pela já citada Linda Hutcheon que, na definição acima exposta, alargou a abrangência do conceito para que incluísse a forma paródica do pós-modernismo, que está menos para a imitação ridicularizadora do que para uma operação lúdica com o seu objeto (Hutcheon, 1991, p. 57).

Assumo aqui a definição de Anjos da Noite como um filme pós-moderno, tal como vem sendo reconhecido nos últimos tempos pela crítica acadêmica. ${ }^{5}$ Não pormenorizarei a caracterização do pós-modernismo no cinema, tema de outro artigo (Pucci Jr., 1996, pp. 211-220); apenas especifico que um de seus traços seria essa paródia lúdica, bem diversa da paródia praticada por exemplo pelo Cinema Marginal, cuja ironia cortante, bem de acordo com o espírito modernista, esmerava-se em ridicularizar os objetos que parodiava. ${ }^{6}$ Não poderia haver cena que melhor servisse de exemplo de paródia pós-modernista do que a da dança sob o MASP. Distanciamento combina-se com a fascinação pelo que atravessa o tempo e o espaço e se reespetaculariza nas mãos do diretor. Recupera-se a magia perdida da época de ouro do cinema, ainda que mesclada à evidência do antinaturalismo. Por um lado, isso já foi motivo para críticas de teor político (Ab'Saber, 1995, pp. 162-164); por outro, estimula a pensar em por que essa fascinação se fez presente na cinematografia brasileira dos anos oitenta, aliás penetrando na década seguinte.

Jean Baudrillard, em suas diatribes contra o mundo contemporâneo, escreveu que "nós só temos direito ao retrô, à reabilitação fantasmática, paródica de todos os referenciais perdidos" (Baudrillard, 1981, p. 66). Diz ele que simular põe em questão a diferença entre

\footnotetext{
4. Celebração suposta por Steven Connor, a meu ver equivocadamente, como característica da cultura pós-moderna (1996, p. 67-68).

5. Ainda que em geral a fim de menosprezar a criação de Wilson Barros, por exemplo em Parente, 1998, pp. 112-113, 126-134.

6. Sobre o escárnio implícito na paródia modernista, v. Santiago, 2002, pp. 108 , 133-4. Quanto às diversas funções de ironia, da agressiva à lúdica e respeitosa, v. Hutcheon, 2000 , pp. 72-88.
} 
verdadeiro e falso (ibidem, p. 16), extrapolando o âmbito da representação. Esta decorre do princípio de equivalência do signo e do real; a simulação, ao contrário parte da negação radical do signo como valor, parte do signo como reversão e morte de toda referência (e tal). Ocorre simulação quando o simulacro possui características de seu objeto, mas não é o próprio objeto, como a pessoa que simula estar doente, possui sintomas da doença, mas não a tem (ibidem, p. 12). A simulação corresponde a um curto-circuito da realidade e a seu redobramento pelos signos (ibidem, p. 48). Um exemplo recente e, portanto, não mencionado no citado livro de Baudrillard (que já tem mais de duas décadas) seria a mencionada mulher de vermelho de Matrix: ela é representação cinematográfica de uma realidade virtual que, por sua vez, na diegese do filme, simula todas as características de um objeto que nem sequer existe. Onde está o real? Sumiu de cena. Isso é o que poderia ser entendido como "curto-circuito" da representação e hipertrofia dos signos. Não por acaso aparece em destaque no início de Matrix um exemplar falsificado de Simulacres et simulation, livro de Baudrillard.

Infelizmente Baudrillard se equivoca ao citar exemplos de simulacro no cinema: Barry Lyndon, Chinatown, Todos os Homens do Presidente, 1900 etc. (Baudrillard, 1981, p. 73). O hiperreal, isto é, a "semelhança alucinante com o real" que Baudrillard alega ver nesses filmes nada mais é do que o velho naturalismo cinematográfico, sempre em sua busca da verossimilhança. ${ }^{8} \mathrm{~A}$ mesma aparência de perfeição visual vem sendo sentida, década após década, desde a invenção do cinematógrafo, especialmente em relação a filmes hollywoodianos, como King-Kong e Ben-Hur, mas nem por isso cogitou-se em chamá-los de "simulacros" no sentido que dá Baudrillard à palavra.

Penso não ser necessário endossar a opinião de Baudrillard sobre a inexistência tanto da realidade como da própria ilusão no

7. O que está longe de provar que o mundo se transformou num imenso simulacro, afinal isso só faz sentido dentro da narração de Matrix.

8. Mesmo engano cometido por Fredric Jameson (1997, pp. 292-301), que atribui pós-modernismo a filmes convencionais como Totalmente Selvagem (Jonathan Demme, 1986). 
mundo atual. Além do mais, é questão para especulações filosóficas, que não cabem no momento, pensar se o real ainda existe ou não. Mais pertinente é apontar que há cineastas para os quais é uma utopia a representação fiel da realidade, mas que nem por isso se abstêm de trabalhar com a imagem cinematográfica que é tida como realista pelo senso comum: a do cinema clássico. Não fazem filmes que replicam as normas desse cinema, mas operam com seus elementos de uma forma lúdica.

Entendo que essa estética tem lugar quando os recursos tecnológicos mais avançados ou custosos meios de reprodução do real são utilizados não para simular a realidade, mas para representála e simultaneamente denunciar o falseamento da imagem. Tratase do que poderia ser chamado de "paradoxo da técnica naturalista": numa época em que a tecnologia digital tornou possível reproduzir o que o senso comum entende como "real" ou "possível", o cinema desvia-se da verossimilhança e introduz o fake. Trata-se de filmes, portanto, em que prevalece não a referencialidade, mas signos colhidos do repertório da tradição do cinema e do audiovisual. Constroem-se imagens e sons que possuem traços de representações clássicas, mas que, ao mesmo tempo, evidenciam que são metacomposições. São os casos de Blade Runner, Diva - Paixão Perigosa, Subway, Dick Tracy, Edward Mãos de Tesoura, Na Roda da Fortuna, dos filmes de Greenaway, de Almodóvar - e de Anjos da Noite.

O filme de Wilson Barros é uma grande caixa chinesa em que é impossível encontrar o fundo, ou seja, a referencialidade. ${ }^{9}$ Estes são mais alguns elementos que se relacionam com a figura um tanto camp de Marta Brum. ${ }^{10}$ "Fascínio" talvez seja mesmo a

9. Utilizo este conceito no sentido utilizado por Jakobson (1970, pp. 123-129) em sua classificação das funções da linguagem: ênfase no contexto. Destaco que considero a relação intertextual, predominante no cinema pós-moderno, como ligada à função designativa (sugerida por Edward Lopes), em que a ênfase está na relação com outra mensagem.

10. Aponto a relação da personagem e do filme com o conceito de camp, tal como proposto nos anos sessenta por Susan Sontag (1987, pp. 318-337): predileção pelo inatural, pelo artifício, pelo exagero etc. Desde a década de sessenta, tais elementos se tornaram muito mais profusos, o que apenas revaloriza o texto de Sontag. 
melhor palavra para evocar a dança sob o MASP; sem que se cogite, porém, qualquer semelhança alucinatória com seu objeto, o filme de Minelli. ${ }^{11}$

\section{O jogo do "como se"}

Marta e Guto terminam a dança, andam pela noite, ela chama um táxi e, devido ao gesto brusco, arrebenta-se o colar, as pérolas caem no chão. Grito histérico da mulher. O rapaz se abaixa para pegá-las, ao que Marta diz: "Deixa isso para lá, meu anjo. São todas falsas. Amanhã a gente compra outro na feira". Seria de se esperar algo diferente em relação ao valor das pérolas?

Mais uma fala de Marta, como sempre repleta de trejeitos e clichês ("Táxi! Meu reino por um táxi" etc.) e vem, em seguida, um momento delicioso. Marta diz que farão como no cinema: fala para Teddy pegar nas suas mãos e fechar os olhos quando ela disser "já". Marta conta: um, dois, três, já. Corte seco e eles aparecem num apartamento, com Marta acabando de acender as luzes. Teddy solta uma exclamação de espanto. O que aconteceu? Numa leitura naturalista, provavelmente comum a muitos espectadores, a montagem teria elidido o caminho de ambos até o apartamento de Marta, de modo que a exclamação de Teddy se referiria à aparência do local, de fato caprichado. Ou, numa leitura auto-referencial, teria havido o transporte instantâneo de um local a outro, "como no cinema". É insolúvel a ambigüidade, como tantas outras no filme. De qualquer forma, existe a alusão metalinguíística às elipses cinematográficas que hoje em dia chegam a passar despercebidas aos espectadores.

Antes de continuar a trajetória de Marta e Teddy, encontro a ocasião de indagar qual é o jogo envolvido. Virtuosismo, fake, fascínio, paródia lúdica, auto-reflexividade, ambigüidades incontornáveis... Com certeza não é o jogo do cinema naturalista, cujo modelo é Hollywood: veja-se o gesto pudico de Marta para a câmera, no momento em que Teddy começa a lhe tirar o vestido (Fig. 9).

11. Note-se que, ao contrário do que propugna Jameson, não considero que a nostalgia seja característica do pós-modernismo. Essa é uma questão complexa, cuja solução pode ser sugerida pela lembrança de que no pós-modernismo exista ironia, não desejo de volta ao passado (Hutcheon, 1991, p. 51). 


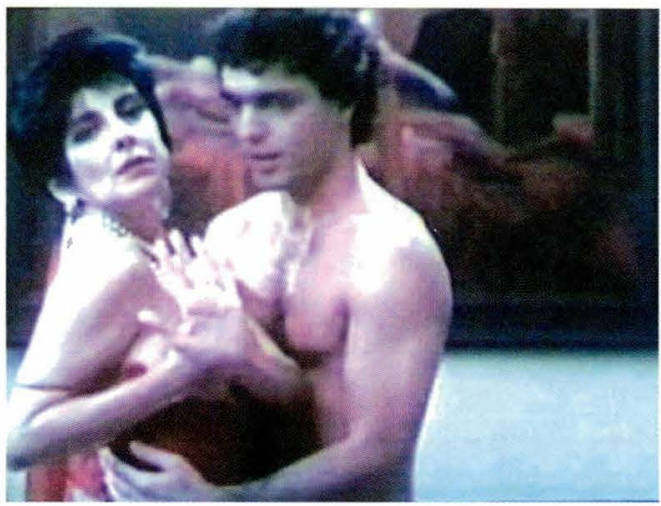

Fig. 9

Anjos da Noite não opera com o ilusionismo, que Roger Caillois relacionou à mimicry, segundo ele uma das quatro categorias do jogo. Não se trata de apagar o caráter discursivo do filme, vendendo-o como real; nem de buscar identificação entre espectador e personagem, outra propriedade da mimicry cinematográfica (Caillois, 1990, pp. 42 43). No entanto, é possível dizer que, antes de mais nada, Anjos da Noite permanece no território do lúdico. Por isso falei em "jogo", atividade que, dentre suas várias características, possui a de ser "evasão da vida 'real' para uma esfera temporária de atividade com orientação própria" (Huizinga, 1996, p. 11). É possível ceder ao fascínio autoconsciente de Anjos da Noite, de modo que a "realidade", suas misérias e preocupações não façam parte da apreciação fílmica. Eis um motivo por que os críticos ligados à herança do Cinema Novo, sério por excelência, criticaram o filme de Wilson Barros. Não há como negar o aspecto lúdico em questão. ${ }^{12}$

Se existe fundamento na idéia de que a experiência cultural é afim à da brincadeira, mesmo a infantil, tal como propõe Winnicott (1975, p. 139), Anjos da Noite poderia ser um exemplo cabal de filme que assume esse caráter. Não faz como o filme clássico

12. Não acredito, porém, que essa fascinação esgote as possibilidades de relacionamento do espectador com o universo de Anjos da Noite. Há provavelmente aspectos políticos envolvidos, ainda que não se trate da política revolucionária que foi típica do Cinema Novo. Esse ponto deverá ser abordado na continuidade da pesquisa de doutorado que ora desenvolvo sobre os filmes pós-modernos brasileiros. 
hollywoodiano, através do qual se pretende mistificar o jogo através da aparência de realidade; nem como o filme moderno, sempre em busca desesperada da originalidade e da utilidade para seus espectadores (politização, desfamiliarização, conhecimento de realidades profundas etc.). ${ }^{13} \mathrm{O}$ que propõe Anjos da Noite? É possível que isso dependa da área transicional de cada espectador, ou seja, do espaço intermediário entre o texto e o espectador, sujeito às mais heterogêneas variações, dependendo da cultura e da disposição deste para jogar com o objeto cinematográfico (Winnicott, 1975, p. 148). Talvez Anjos da Noite promova o jogo de descoberta das infinitas referências à história do cinema e da cultura (como o Shakespeare da última citação de Marta Brum). Talvez provoque prazer com o oscilar entre, de um lado, o estado de quase alheamento que o filme pode produzir e, de outro, o escancarar da auto-reflexividade. Talvez permita o gozo com a idéia de que as coisas nunca são o que são, isto é, de que tudo é jogo - idéia bem afinada com o espírito pós-modernista. Marta Brum seria, nesse sentido, a condensação dessas e de outras possibilidades, a mais perfeita encarnação do "como se", isto é, do jogo fílmico pós-moderno.

\section{Minutos de prorrogação}

Marta e Teddy passam a noite juntos. De manhã, ele se levanta, furta alguns bibelôs, deposita o último e estereotipado beijo em Marta (Fig. 10). Vai embora.

\section{Fig. 10}

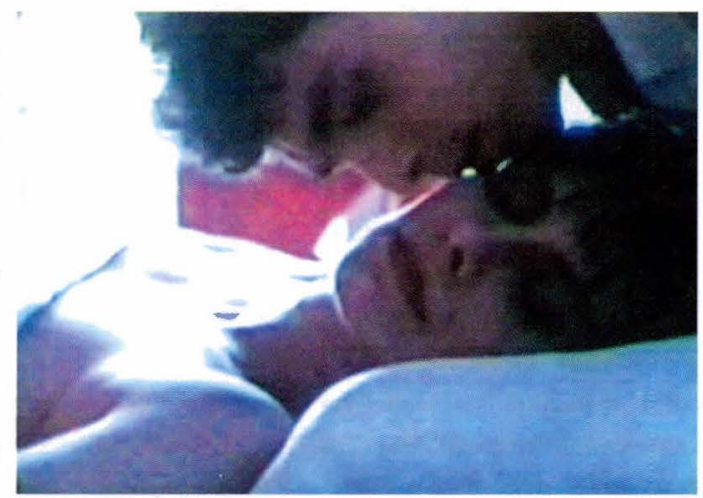

13. O que não significa que filmes modernos também não tenham jogos implícitos, bem diferentes dos de outras linhas estéticas. Apenas que a relevância desse aspecto lúdico e prazeroso não é assumida nos próprios filmes, que, em geral, marcam-se pela seriedade. 
Numa praça, ainda nos primeiros minutos do dia, Teddy passa por uma garota sentada num banco. É Ciça, a estudante de sociologia que terminou frustrada e solitária sua inesperada noite de orgia. Teddy, que nunca a havia visto antes, volta, senta-se ao lado e puxa conversa. Ele percebeu a tristeza da moça. Diz-lhe palavras reconfortantes, sempre em frases feitas ("A vida é difícil e boa. Mas vale a pena."), acalma-a tão bem que se despedem como velhos amigos. Mas Teddy põe a mão no bolso e descobre as pérolas de Marta Brum. Chama Ciça e lhe entrega as pérolas como presente (Fig. 11). A moça pergunta se são verdadeiras. Resposta de Teddy: "E isso importa? Importa que elas são lindas. E agora são suas." Não poderia haver melhor síntese da estética do filme, discutível com certeza, porém assumida com toda consciência, como o indica a cena descrita.

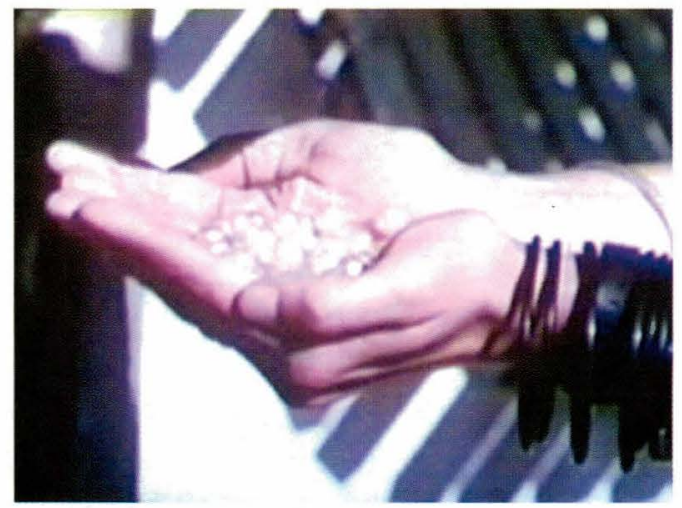

Fig. 11

O que poderia estar na origem de uma estética como a de Anjos da Noite? A adesão inconseqüente a princípios que proliferavam no cinema internacional? Considerando-se a penetração da estética pós-moderna em nosso meio, ${ }^{14}$ não parece absurdo pensar

14. Cito exemplos de filmes nacionais que compartilham traços apontados em Anjos da Noite: Cidade Oculta (Francisco Botelho, 1986), A Dama do Cine Shangai (1988) e todos os filmes posteriores de Guilherme de Almeida Prado; Fogo e Paixão (Márcio Kogan e Isay Weinfeld, 1988); Lili, a Estrela do Crime (Lui Faria, 1988); Carlota Joaquina, Princeza do Brasil (Carla Camurati, 1995); A Grande Arte (Walter Salles Jr., 1991); Terra Estrangeira (Walter Salles Jr. e Daniela Thomas, 1995); Dias Melhores Virão (1989) e Orfeu (1999), ambos de Carlos Diegues; o episódio da ninfeta, dirigido por Cláudio Torres, em Traição (1999). 
que poderia estar acontecendo também no Brasil aquilo que Lyotard havia anunciado na década de setenta como a condição pós-moderna: "o estado da cultura após as transformações que afetaram as regras dos jogos da ciência, da literatura e das artes a partir do fim do século XIX" (Lyotard, 1979, p. 7). A descrição de Lyotard deveria valer para as sociedades avançadas: hegemonia dos meios de comunicação de massa, informatização generalizada, dissolução do sujeito social, mercantilização do saber, abalo da crença em grandes narrativas (como o marxismo, que em sua versão nacional mais singela havia anunciado a revolução brasileira para os anos sessenta), desvalorização da idéia de "verdade" e preeminência da performance. Entretanto, por mais que alguns desses princípios sejam contestáveis, será que já não estavam se disseminando no panorama nacional dos anos oitenta? De qualquer modo, encontrava-se ainda na virada do milênio a estética pós-modernista-entre as várias opções estilísticas à disposição dos cineastas.

Por que então se admirar que um filme como Anjos da Noite termine com a apologia do que é lindo e fake? Ou por que se espantar com o virtuosismo da cena da torre esvoaçando sobre o rosto de Marta Brum, tão radiante e falsificada como suas pérolas?

\section{Bibliografia}

AB'SABER, Tales A. Muxfeldt. 1995. O Cinema Paulista dos Anos 80: um Problema da Cultura. São Paulo. Dissertação (mestrado). Universidade de São Paulo, Escola de Comunicações e Artes.

BAUDRILLARD, Jean. 1981. Simulacres et simulation. Paris: Galilée.

BORDWELL, David. 1985. Narration in the Fiction Film. Madison: University of Wisconsin Press.

CAILLOIS, Roger. 1990. Os Jogos e os Homens. Lisboa, Cotovia.

CONNOR, Steven. 1996. Cultura Pós-Moderna. 3.ed. São Paulo: Loyola 
HUIZINGA, Johan. 1996. Homo Ludens. 4.ed. São Paulo: Perspectiva.

HUTCHEON, Linda. 1991. Poética do Pós-Modernismo. Rio de Janeiro: Imago.

2000. Teoria e Política da Ironia. Belo Horizonte: UFMG.

ISER, Wolfgang. 1980. The Act of Reading. Baltimore e Londres: Johns Hopkins University Press.

JAKOBSON, Roman. 1970. Lingüística e Comunicação. São Paulo: Cultrix.

JAMESON, Fredric. 1997. Pós-Modernismo - A Lógica Cultural do Capitalismo Tardio. 2.ed. São Paulo: Ática.

LYOTARD, Jean-François. 1979. La condition postmoderne. Paris: Minuit.

PARENTE, André. 1998. Ensaios Sobre o Cinema do Simulacro. Rio de Janeiro: Pazulin.

PUCCI JR., Renato Luiz. 1996. "Cinema Pós-Moderno". Significação - Revista Brasileira de Semiótica. São Paulo. N. ${ }^{\circ}$ s 11/12, setembro, págs. 211-220.

SANTIAGO, Silviano. 2002. Nas Malhas da Letra. Rio de Janeiro: Rocco.

SONTAG, Susan. 1987. Contra a Interpretação. Porto Alegre: L\&PM.

WINNICOTT, D. W. 1975. O Brincar \& a Realidade. Rio de Janeiro: Imago. 